\title{
LEARNING STRATEGIES AND EVALUATION METHODS IN DANCE EDUCATION
}

\section{SUMMARY}

Introduction. The article deals with the problem of stimulation of the changes in teaching dance at schools seeking to implement contemporary approach to education based on active learning process and apropriate evaluation for learning. The object of the research is learning strategies and evaluation methods in dance education.

The Aim of the Study. To define pecularities of learning strategies and evaluation methods in dance education at school.

Materials and Methods. Analysis of scientific literature, European and Lithuanian education documents; questionnaire of 168 dance teachers of Lithuania, diagnostic investigation with 159 students in Grades 5-6 from two Vilnius basic schools; pedagogical experiment with 65 students in Grades 5-6 from one Vilnius basic school where dance lessons are held once a week; interview with four students from the pedagogical experiment; descriptive statistics.

Results. The results of the research showed that learning strategies are hardly implemented in dance education process; mostly a bihevioristic approach in teaching is used where the emphasis is laid on showing and explaining the dance steps connected with aural and visual learning styles and the main method of evaluation is the repetition of the dance steps shown.

Conclusions. It has been concluded that mostly one (folk or ballroom dance) genre is used and one activity (mostly performance) is applied, though efficient educational process in dance is implemented through a combination and proportional application of dance activities, tasks connected with all learning strategies most appropriate to every student and evaluation instruments which include creative tasks with clear evaluation criteria and individual development subgoals. Keywords: dance education, learning strategies, evaluation methods

\section{INTRODUCTION}

Education today constantly experiences new challenges related to political, economical, social and cultural life changes, problem solving and meeting different requirements. Responsible citizen, active specialist, empathic functionary, creative person seeking meaningful participation in the political, economical, social and cultural life of community needs to acquire certain competencies in various fields of life. Therefore European and Lithuanian documents of education (Provisions of the National Education Strategy for 2003-2012, 2003; Changing Teaching Practices, 2004; Conception of Children and Youth Cultural Education, 2008; General Programs for Primary and Basic Education, 2008, etc.) orientate main principles of efficient education towards educating basic competencies in languages, mathematics, natural and social sciences, arts. Competencies are understood as the whole of values, skills, knowledge and understanding which enables students to act successfully in a certain field of life (Recommendation of the European Parliament and of the Council on Key Competences for Lifelong Learning, 2005).

The object of the research is learning strategies and evaluation methods in dance education.

\section{THE AIM OF THE STUDY}

To define pecularities of learning strategies and evaluation methods in dance education at school. 


\section{Goals of the research are:}

1. To analyze dance education process and activities;

2. To define factors that influence learning strategies in dance education;

3. To devise evaluation instruments in dance education.

\section{MATERIALS AND METHODS}

The Lithuanian education reform (started in 1988) based on a shift of the educational paradigms from classical towards free revealed a new approach to the strategies of teaching and learning, understanding roles and abilities of teachers and students. The main difference of these paradigms is related to the relation to the personality of a student, is there a cooperation or operation with the personality (Brūzgelevičienè, Žadeikaitè, 2008). Lithuanian education scholars revealed that in Lithuanian schools there is still very strong tradition of operation with the personality, when student is passive in learning process and subject is in the centre of teaching. While free education paradigm emphasizes active role of a student in learning and pedocentristic approach towards teaching. Especialy motivation, wish and positive attitude of acquiring new knowledge of a student is underlined (Aramavičiūtè, Martišauskienè, 2006).

Problems mentioned above are relevant to dance education, too. Though all required documents (constantly renewed general education programs, compiled recommendations for execution of education contents, etc.) are present teaching of dance at schools is fragmented and inconsequent. This arises because usually dance at schools is implemented as informal activity in dance studios, collectives, etc. Besides dance is optional study subject and offer of this subject depends on a school master's good will and understanding of the importance of arts education. While music and visual art subjects are traditionaly compulsory. Dance in Lithuanian educational system was formalized in 1997 when the first programme of dance (then it was named programme of choreography) appeared. Later in 2002 General Dance Program for XI-XII grades appeared together with the programs of other subjects of general education. In 2003 General Dance Program for all education stages from pre-school and primary to basic and secondary was created and renewed in 2008 according to European guidances for education.

Regardless of documetary created favourable conditions dance as a one of the subjects of arts education is hardly accepted as necessary for everyone seeking become well educated, creative, active and open member of the community, citizen of the state (Goodlad, 1992; Fowler, 1996; Jackūnas, 2000; Matonis, 2005). In general society dance is still understood as a way of preparing talented children for further professional life or oposite, as leisure informal activity. Predominated for a long time behaviouristic approach in dance teaching too much emphasized satisfaction of spontaneous self-expression and paid not enough attention to education of creative artistic skills and aesthetic competencies. Distinct orientation towards development of dance technique and participation in numerous concerts and competitions was obvious. However, this situation dismiss both teachers, students and society needs and principles of contemporary education. Therefore the scientific problem arises how to stimulate the change in teaching dance at schools in order to implement contemporary approach to education based on active learning process.

According to Matonis (Matonis, 2005), cognitive arts education theory which appeared in second half of XX century promotes transition from teaching techiques and procedures which are easy quantifiable towards education of wholly understanding of arts phenomenon, arts cognition and communication and education of skills and attitudes required. New paradigm of arts education and application of European dimensions determine relevance of learning strategies in dance very much connected with appropriate, orientated towards learning evaluation process.

In dance teachers questionnaire survey 168 dance teachers from different regions of Lithuania, representing all age groups, qualification and experience levels participated. In diagnostic investigation 159 students of 5-6 grades from two Vilnius basic schools where dance 
lessons are held participated. Pedagogical experiment included 65 students of 5-6 grades of one Vilnius basic school where dance lessons once a week were held. For the interview four students from pedagogical experiment group were chosen.

Dance education process and activities. Dance education as formal education where broad knowledge of dance should be given is organized in schools as dance lessons similar to lessons of other subjects. As it was mentioned before dance lessons are not compulsory, but optional. In Lithuania in the regulations for schools annual study plans it is reccomended that in primary grades one of three sports lessons could be used for dance. That means, if the class and parents and teachers decide and school headmaster accepts, all students from particular class will attend dance lessons through whole school year. Though it does not mean that next year dance lessons would be offered for the same class again. As questionnaire survey of dance teachers revealed nearly $60 \%$ respondents reported that there are dance lessons at primary schools, $30 \%$ in senior classes (11-12 grade) and only 10\% - in 5-10 grades. These results reveal fragmented dance education process which does not support achievement of foreseen education goals in General Dance Program as part of General Education Program - to enhance dance competencies which include consequent and sustainable dance knowledge, skills and attitudes. Dance teachers pointed out that it is very hard to seek foreseen achievements in one year as in the Program they are formulated for two years period.

The survey stated that organizing dance education process mostly dance teachers use lithuanian folk dance especially in primary grades and ballroom dance - in 11-12 grades (see Table 1).

Table 1. Dance genres used in education process

\begin{tabular}{|c|c|c|c|c|}
\hline \multirow{2}{*}{ Grades } & \multicolumn{4}{|c|}{ Dance genres } \\
\cline { 2 - 5 } & $\begin{array}{c}\text { Lithuanian folk } \\
\text { dance }\end{array}$ & Ballroom dance & Contemporary dance & Other dance genres \\
\hline $1-4$ & $82.7 \%$ & $10.1 \%$ & $3.6 \%$ & $3.6 \%$ \\
\hline $5-10$ & $44.3 \%$ & $21.6 \%$ & $17.3 \%$ & $16.8 \%$ \\
\hline $11-12$ & $19.3 \%$ & $41.2 \%$ & $23.7 \%$ & $15.8 \%$ \\
\hline
\end{tabular}

These results showed that mostly dance teachers concentrate in one dance genre in spite of using all of them according to age and abilities of students and combining them in order to give more broad understanding of dance and depen dance vocabulary of students. Some of teachers mentioned that they use other dance genres such as historic dance, jazz dance, ballet or line dances. The variety of used dance genres in education process appears from 5th grade and teachers explain this stating that in that age students are more able to learn certain steps from particular culturaly determinated dance kinds, i. e. genres. In early age simple folk dances, games and cirlce dances are more suitable as they do not demand from students long term memory and complicated coordination of body parts. These results could be confirmed by investigations of other authors (Guest, 1983; Lindqvist, 2001, etc.) who indicate that the most appropriate age for learning formalized dance steps is 9 years which coinside with 4-5 th grades.

The other aspect of dance process was examined by dance activities used in education process. The results of dance teachers' survey showed that main activity of dance is teaching dance steps, especially this vivid in primary grades (see Table 2).

It is dramatic that a very low rate of dance teachers use creative tasks in the dance education process explaining that children cannot create dances. Though in private discussions dance teachers admit that they themselves were not taught to create dances, except for recreating already created folk or ballroom dances. Very few teachers teaching contemporary dances stated that they improvise and compose together with their students. In the learning period in Grades 5-10 
Table 2. Dance activities used in education process

\begin{tabular}{|c|c|c|c|c|}
\hline \multirow{2}{*}{ Grades } & \multicolumn{4}{|c|}{ Dance activities } \\
\cline { 2 - 5 } & Teaching dance steps & Creating dance & $\begin{array}{c}\text { Observing and } \\
\text { analyzing dance }\end{array}$ & Combining activities \\
\hline $1-4$ & $61.7 \%$ & $4.4 \%$ & $4.7 \%$ & $29.2 \%$ \\
\hline $5-10$ & $19.1 \%$ & $22.3 \%$ & $33.8 \%$ & $24.8 \%$ \\
\hline $11-12$ & $36.7 \%$ & $11.1 \%$ & $10.0 \%$ & $42.2 \%$ \\
\hline
\end{tabular}

a wider range of dance activities is revealed. Less emphasize on teaching dance steps is explained by dance teachers by lower motivation of students to repeat the same steps, which become borring for active and independent personalities of adolescents. But not a lot of them too are interested in creative activities as there is this crusial moment of subsidence of spontaneous creativity and weakened interest for artistic creation as it is stated in works of arts psychology scholars. That is why more dance observing and analyzing activities are used in education process in Grades 5-10.

In Grades 11-12 it is noticed return to teaching dance steps as in primary grades. This could be explained that in 11th grade students can choose dance lessons as one of artistic education subjects and sometimes it happens that until that time students have not had dance experience, so they act as beginners. Students state that for them it is easier to repeat what dance teacher show as they have an example of right dance patterns and repetition of them makes students feel safe. Though teachers try to combine more dance activities as they assume that in senior classes students are more ready to discuss dance, to evaluate it, understand complicate relations and contexts.

Though pedagogical experiment and pedagogical observation revealed that most efficient achieving dance education goals is sequental and purposeful involment of students into autonomus dance activities - performance, creation (including improvisation and composition), observation, interpretation and evaluation (Banevičiūtè, 2009). These dance activities are combined seeking to develop dance competencies as the goal of dance education (see Picture 1).

Picture 1. Interrelations of dance activities in education of dance competencies

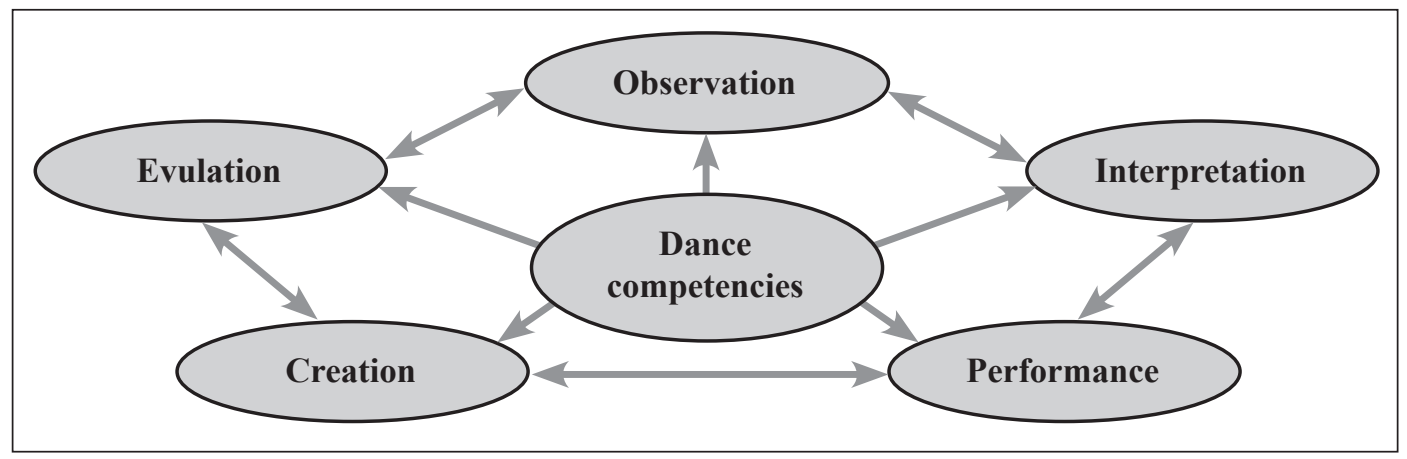

As it is stated in General Dance Program (2008) the proportion of these dance activities in education process varies according to stage of education, age, psychological and physiological abilities of students (see Table 3). In preschool and primary school grades significant part of education process is dedicate to dance performance and creation as younger students are more physically active and need to expand their kinesthetic abilities and creative skills as well as gain wider dance vocabulary, which doesn't mean to be connected with learning dance steps, but more related to experimenting with basic movements such walks, jumps, runs, turns, rolls, etc. These actions are emphasized by most of dance education scholars (Smith-Autard, 2002; Banevičiūtè, 2009, etc.) as 
the background of expanding dance skills. Starting from basic education stage it is recommended to expand part of activities related to dance observation, interpretation and evaluation.

Table 3. Dance activities in education process

\begin{tabular}{|c|c|c|}
\hline Stage & Grades & \multicolumn{2}{|c|}{ Dance activities } \\
\hline \multirow{3}{*}{ Basic } & $11-12$ & \multirow{3}{*}{ Observation, interpretation, evaluation } \\
\cline { 2 - 2 } & $9-10$ & \multicolumn{3}{|c}{ Performance, creation } \\
\cline { 2 - 2 } & $7-8$ & \\
\cline { 2 - 2 } & $5-6$ & \\
\hline \multirow{2}{*}{ Primary } & $3-4$ & \\
\hline & $1-2$ & \\
\hline Preschool & & \\
\hline
\end{tabular}

Dance activities, dance genres used in education process of dance education, development of dance competencies very much are connected with the organization of dance education process from the point of application of teaching and learning strategies which influence significantly the higher achievements in dance education.

Learning strategies in dance education. There are a number of different names and classification systems for learning strategies. Sometimes learning strategies are defined as learning styles, i. e. ways in which students acquire knowledge most efficient for themselves. As stated kinesthetic, aural, visual ways of learning are revealed among students. In dance education these learning styles could be seen as such activities: 1) student likes to watch at the begining movement patterns of dance teacher or other student and then try (visual), 2) student tries at the begining together with teacher or other student or even by himself (kinesthetic), 3) student likes to hear explanations at the begining how to do certain steps and then try (aural). There is one more learning style mentioned in educational literature, when student learn most efficient while explaining study material to others. That could be called oral way of learning.

It is evident that different students have different learning styles and they should be given an opportunity to learn in most sufficient way for them. However it is stated (Fowler, 1996; Goodlad, 1992) that at schools mostly one style is appreciate - aural, as teachers more often start from explaining the task instead of giving students an opportunity to try variuos ways of learning. The survey of dance teachers revealed that mostly they present tasks which demand visual and aural way of learning (see Table 4).

Table 4. Task giving and related learning strategies

\begin{tabular}{|c|c|c|c|c|}
\hline \multirow{2}{*}{ Grades } & \multicolumn{4}{|c|}{ Task presentation } \\
\cline { 2 - 5 } & $\begin{array}{c}\text { Explaining } \\
\text { (aural) }\end{array}$ & $\begin{array}{c}\text { Showing } \\
\text { (visual) }\end{array}$ & $\begin{array}{c}\text { Trying } \\
\text { (kinesthetic) }\end{array}$ & Combining strategies \\
\hline $1-4$ & $43.7 \%$ & $38.4 \%$ & $13.2 \%$ & $4.7 \%$ \\
\hline $5-10$ & $26.1 \%$ & $27.3 \%$ & $30.8 \%$ & $15.8 \%$ \\
\hline $11-12$ & $16.7 \%$ & $38.3 \%$ & $15.6 \%$ & $29.4 \%$ \\
\hline
\end{tabular}

Dance teachers stated that usualy in primary grades they show and explain dance steps at the same moment. This is not appreciated by most of dance education scholars (SmithAutard, 2002; Banevičiūte, 2009) as at the same time students especially in early age are not able to receive and perceive information from different sources. So it is recommended to devide presentation of the teaching information - to use only one way at one moment. If it is needed to show dance steps first without words, then explain how to perform them. But the pedagogical experiment showed that most eficient way is to show dance steps first and give students time to 
try themselves and only then ask qustions and explain if it is needed. Another approach to task presentation pattern was examined in diagnostic investigation and showed high efficiency is to distribute students into groups of four-five people and let them try the tasks without explaining or showing. The results of the investigation revealed that mostly in all groups there appeared students who already know dance steps or have ideas for creation or interpretation of dance. While working in groups students share their experience, find different and original ways of solving given tasks. At the same time they learn how to communicate with each other, tolerate different opinions, accept them, negotiate and find best solutions.

Mentioned above learning styles in dance education could be analyzed from so called "metacognitive" and "task-based" approach. The metacognitive strategies can be used for almost any task and are based on reflecting on one's own thinking while the task-based learning strategies are more determined by the specific nature of the task and the resources of the student.

Metacognitive learning strategies are general learning strategies. Reflecting upon your own thinking and learning is metacognitive thinking (Marzano, 2005). Once students begin to think about their own learning, they can then begin to notice how they learn, how others learn, and how they might adjust how they learn to learn more efficiently. Four general metacognitive strategies could be listed with related questions that students could ask themselves: organize/ plan (What do I do before I start?), manage (What do I do while I am working on the task?), monitor (How do I make sure I am doing the task correctly?) and evaluate (What do I do after I have finished the task?) your own learning. These metacognitive strategies follow the sequential order of the process a learner generally goes through in accomplishing any task. However, learners are not as linear as this suggested model. In reality, students go back and forth: planning, then monitoring, then planning again, managing, organizing, etc.

The 'task-based' learning strategies focus is on how students can use their own resources to learn most effectively. They could be divided into four categories that are grouped by the kinds of resources students already have, or can get, to help them complete specific tasks: use what you know, use your imagination, use your organizational skills, use a variety of resourse. By focusing students' attention on their resources, their ability to take responsibility for their own learning is emphasized.

To acomplish these learning strategies in dance education dance education process should include tasks that demand from students' abilities to watch dance, to hear comments and explanations of dance, to dance and create dance, to share experience and give evaluation of dance or their experience in dance. The educational model which included these aspects was examined in the pedagogical experiement and the results of experiment indicated the efficiency of organizing dance education process in such a way (Banevičiūtè, 2009). The background of this model relates to the cognitive approach to learning in dance education as acquiring skills in thinking and communicating by means of dance, i. e. manipulating and understanding of dance elements in order to create and perceive meaning. The pecularity of the model is presented in communication situations which are created during the education process, where student communicate through created dance work and directly collaborate with the teacher (see Picture 2).

The experiment showed importance of before and after the accomplishment of tasks asking students questions which induce thinking processes, such as, what does it remind to you, why you feel like that, do you have creative ideas, what are these ideas, why you chose this idea, how it could be done in another way, what do you feel about the task, how would you improve your task, etc. After the performance of the task, especially when it is related to dance creation, it is important to talk with students and find out their self-evaluation, then evaluation of each others work and only then teacher can present his opinion, more like 


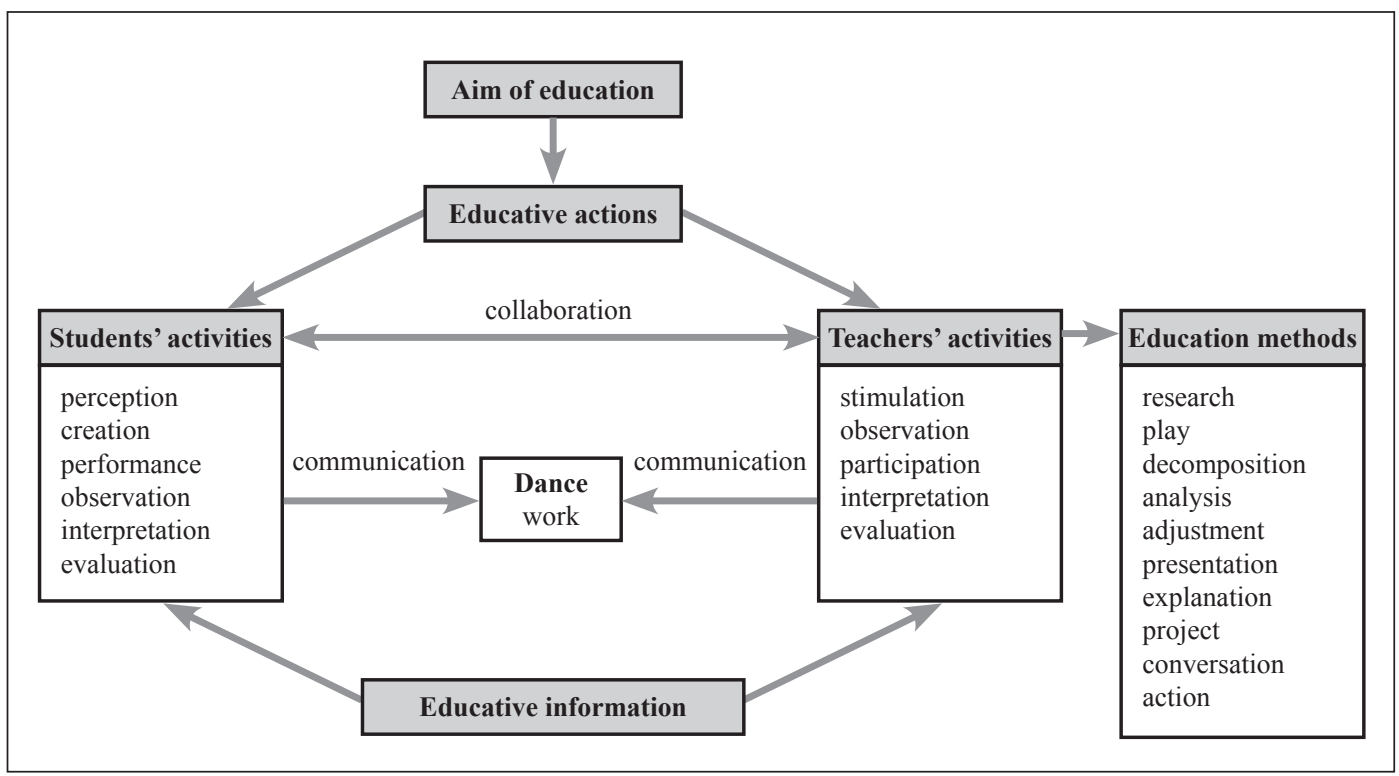

summary of all what was said. It was mentioned in the interview of students who participated in pedagogical experiment that for them it was very important to express their feelings about their dancing afterwards and to hear other students' comments on their work. This especially relates to adolescence age when opinion of friends is more important than opinion of teachers (Banevičiūtè, 2009).

\section{Evaluation methods in dance education.}

One of the most urgent issues of education on a whole and especially in arts education is evaluation. Most researchers (Kazragytè, 2002; Aramavičiūtè, Martišauskienè, 2006; Banevičiūte, 2009, etc.) emphasize that it is very important to apply appropriate evaluation methods and strategies for improving students development, so called assessment for learning strategy. There is still ongoing discussion should achievements in arts education be evaluated, how and when.

The results of dance teachers survey and diagnostic investigation revealed that mostly in dance education there is only one evaluation method is used - technical performance, which quality is evaluated on a criteria of "how precisely student repeat what teacher have showed". This reveals bihevioristic approach to dance teaching when only vivid behavior of a student, usually imitation, is evaluated and objective features as performance execution are assessed. More than $60 \%$ of dance teachers don't ask student to evaluate themselves and about $50 \%$ don't explain to students what they expect from them and what they assess. When students receive a " $C$ " or " 6 " on an assignment and then a "B" or " 8 " on the next, they know that their marks went up, but they do not usually know why. And they do not know what new skill or strategy they need to move up to an "A" or " 10 ". These evaluation strategies are hardly could be called strategies as they are totally chaotic and does not have clear calendar of freaquency or purpose. This situation is more dramatic in Lithuanian as in General Dance Programs (since 2002) is clearly stated achievement standarts and in 2008 even evaluation criteria and achievement level indicators are presented. Still more than $70 \%$ of dance teachers state that they can't create and present tasks which would be appropriate to examine dance achievements, especially for evaluation of dance creation or interpretation. 
In the pedagogical experiment in which creative tasks formulated on a basis of cognitive approach to dance learning were used for dance achievements showed that incorporation of different activities in the assesssment task, such as performance, creation, interpretation, observation, evaluation and clear checklist of learning subgoals, is efficient in achieving more higher levels in dance education. At the begining of the experiment students get to know the whole contents of education process and assesment tasks with clear evaluation criteria which were discussed with students and personal subgoals where set. During all period of experiment evaluation strategies periodically where discussed with students, setting time for self-evaluation, evaluation of each other and analysis of teachers' evaluation. This model helped to avoid situation when dance teachers (and school or local administration) measure their creative and pedagogical success by how successful the students are as they participate in variuos concerts, competitions, festivals, win high places, but learning process is forgottens, as students are evaluated according to the assesment level of the highest standart and there is no attention to personal growth and progress.

The main problem for dance teachers was to understand that evaluation is not just the final concert at the end of the school year, but it is something to be done every day and every lesson and for every task and process, as in order to improve their learning students have to get assesments for every task. They seek the understanding if they are right and moving forward in the context of their own progress.

\section{CONCLUSIONS}

1. The analysis of Lithuanian and European education documents allows stating that on the documentary level all appropriate conditions for dance education at schools have been provided, though in an educational reality of the dance teachers the survey showed that dance education is fragmented and inconsequent.

2. As stated in the General Dance Program, the dance education process in the formal education system includes various dance genres and dance activities such as performance, creation, observation, interpretation and evaluation; however, the survey revealed that mostly one (folk or ballroom dance) genre is used and only one activity (mostly performance) is done.

3. The results of the dance teachers' survey indicated that the emphasis in dance education is on showing and explaining dance steps connected with aural and visual learning styles; it also revealed that learning strategies are clear neither to students nor to dance teachers as are the evaluation purposes and criteria, especially in dance creation and interpretation activities.

4. The diagnostic study and pedagogical experiment substantiated educational process in dance through combination and proportional application of dance activities, tasks connected with all learning strategies most appropriate to every student and evaluation instruments which include creative tasks with clear evaluation criteria and individual development subgoals.

\section{REFERENCES}

1. Aramavičiūtė, V., Martišauskienė, E. (2006) Vertybių ugdymas - pedagoginių kompetencijų pamatas [Development of Values as a Foundation for Pedagogical Competencies]. Pedagogika, T. 84, p. 3337. (in Lithuanian)

2. Banevičiūtè, B. (2009) Šokio gebèjimu ugdymas ankstyvojoje paauglystëje. Daktaro disertacija. [Education of Dance Skills in Early Adolescence]. Vilnius: VPU, 145 p. (in Lithuanian)

3. Brūzgelevičienè, R., Žadeikaitè, L. (2008) Ugdymo paradigmų kaita XX-XXI a. Sandūroje - unikalus Lietuvos švietimo istorijos reiškinys [The Shift in the Educational Paradigm of the Late $20^{\text {th }}$ and the Early $21^{\text {st }}$ Centuries is a Unique Phenomenon in the History of Lithuanian Education]. Pedagogika, T. 89, p. 18-28. (in Lithuanian)

4. Changing Teaching Practises: Using Curriculum Differentiation to Respond to Students' Diversity. (2004) Paris: United Nations Educational, Scientific, and Cultural Organization, 112 p. 
5. Fowler, Ch. (1996) Strong Arts, Strong Schools. New York: Oxford Un-ty Press, p. 87-88.

6. Goodlad, J. I. (1992) Meno vieta mokymo plane [Place of Arts in Education Curriculum]. In: Šiuolaikinés meninio ugdymo koncepcijos. Sud. V. Matonis (2000) [Paradigms of Contemporary Arts Education.] V. Matonis (Ed.). Vilnius: Enciklopedija, p. 25-41. (in Lithuanian)

7. Guest, A. (1983) Your Move: A New Approach to the Study of Movement and Dance. London: Gordon and Breach Publishers, $314 \mathrm{p}$.

8. Jackūnas, Ž. (2000) Meninio ugdymo vieta integruoto mokymo sistemoje [The Place of Arts Education in the Context of Integrated Education]. Šiuolaikinès meninio ugdymo koncepcijos. Sud. V. Matonis. Vilnius: Enciklopedija, p. 183-191. (in Lithuanian)

9. Kazragytė, V. (2002) Komunikacinis priešmokyklinio amžiaus vaikų vaidybos gebėjimų ugdymo modelis [Communication Model of Education of Acting Skills in Preschool]. Pedagogika, T. 62, p. 51-56. (in Lithuanian)

10. Lindqvist, G. (2001) The Relationship between Play and Dance. Research in Dance Education, Vol. 2, No. 1, p. 41-52.

11. Marzano, R. J. (2005) Naujoji ugdymo tiksly taksonomija [New Taxonomy of Education Goals]. Vilnius: Žara, 154 p. (in Lithuanian)

12. Matonis, V. (2005) Changing Attitudes of Arts Education Theories in the Context of Contemporaneity. Pedagogika, T. 78, p. 116-120.

13. Pradinio ir pagrindinio ugdymo bendrosios programos. Meninis ugdymas. Šokis: mokiniu pasiekimai, turinio apimtis, vertinimas (2008) [General Programs of Primary and Basic School. Artistic Education. Dance: Achievements, Content, Evaluation]. Vilnius: LR ŠMM, ŠPC, p. 301-310, 1121-1135. (in Lithuanian)

14. Recommendation of the European Parliament and of the Council on Key Competences for Lifelong Learning (2005). Brussels: http://europa.eu.int/comm/education/policies/2010/objectives _ en.html\#basic (10.01.2010.)

15. Smith-Autard, J. M. (2002) The Art of Dance in Education. London: A\&C Black Publisher, 227 p.

16. Vaiku ir jaunimo kultürinio ugdymo koncepcija [Conception of Children and Youth Cultural Education]. (2008) Vilnius: LR ŠMM, ŠAC, 24 p. (in Lithuanian)

17. Valstybines švietimo strategijos 2003-2012 metu nuostatos [Provisions of the National Education Strategy for 2003-2012]. (2003) Vilnius: LR Seimo nutarimas, 2003 m. liepos 4 d., Nr. IX-1700. (in Lithuanian)

Asist. Dr. Birute Banevičiūtè

Vilnius Pedagogical University

The Institute of Cultural and Arts Education

Address: Studentų 39, Vilnius LT-08106, Lithuania

Phone: +370 61048408

E-mail: birute@atviramokykla.lt 